Univerzitet umetnosti u Beogradu, Interdisciplinarne doktorske studije - Teorija umetnosti i medija, Beograd

DOI 10.5937/kultura1234152V

UDK 316.723:316.77(497.13)"1945/1991"

316.723(=163.41)(497.13)"1945/1991"

originalan naučni rad

\title{
MEDISSKAKULTURA OURCANA
}

Sažetak: Istraživanje medijske kulture članova ruralne mikrozajednice Đurčića na Papuku u Slavoniji 1945-1991. ukazuje na integraciju stanovnika u odnosu na globalne tokove u jugoslovenskoj socijalističkoj državi, a time i u Makluanovo (Marshall McLuhan) globalno selo, i to s obzirom na njihove ekonomske mogućnosti. Recepcija štampe, filma, radija i televizije odvija se na kolektivnom nivou, obrascu karakterističnom za ,folklorno" uopšte, što omogućuje da u okrilju porodične i seoske zajednice dođe do stvaranja habitusa medijske kulture. Prihvatanjem novih medija, prema starim obrascima is određenim generacijskim odstupanjima, potvrđuje Hobsbaumovu (Eric Hobsbawm) tezu da seoske tradicionalne, patrijarhalne, zajednice nisu zatvorene $i$ fosilizovane, i da je njihov opstanak moguć upravo zahvaljujući promjenama koje se odvijaju, jer novi mediji i u ovoj mikrosredini imaju integrativnu funkciju.

Ključne riječi: medijska kultura, Đurčići, socijalistička Jugoslavija, identitet

Dok su četrdesetih godina dvadesetog vijeka novi oblici kulturne industrije, koje su opisali Horkhajmer (Max Horkheimer) i Adorno (Theodor W. Adorno), film, radio, časopisi, stripovi, reklame i štampa, počeli ispunjavati slobodno vrijeme i našli se u središtu kulturnih i komunikacionih sistema u Sjedinjenim Državama i ostalim kapitalističkim državama, tek s pojavom televizije u periodu poslije Drugog svjetskog rata, medijska kultura postaje dominantna sila u oblasti kulture, socijalizacije, politike i društvenog života. ${ }^{1}$ Kelner (Douglas Kellner) smatra da medijska kultura u Sjedinjenim Državama, kao i u većini kapitalističkih zemalja, predstavlja najvećim dijelom komercijalni

1 Kelner D., Medijska kultura: studije kulture, identitet i politika između modernizma i postmodernizma, Beograd 2004, str. 27. 
oblik kulture, koji se stvara radi profita i distribuira u obliku robe. Komercijalizacija kulture i njeno pretvaranje u robu imali su dalekosežne posljedice - stvaranje proizvoda s najnižim zajedničkim imeniteljem. Ono što suštinski razlikuje popularnu ili masovnu kulturu, kako je naziva Janjetović, od tradicionalne, narodne, kulture je činjenica da se proizvodi srazmjerno malog broja ljudi prenose velikoj masi, najčešće uz primjenu raznih tehničkih pomagala - u najširem značenju riječi. ${ }^{2}$

Da tehnologija stvara vlastiti svijet, konstatovao je Makluan (Marshall McLuhan) šezdesetih godina prošloga vijeka: Niko ne želi kola dok se ona ne pojave, i nikog ne zanima televizija dok se ne pojave televizijske emisije. ${ }^{3}$ Sama masovna proizvodnja neke stvari (na primjer informacija), smatra Šušnjić, ne čini od ljudi masu, te su stoga sredstva masovnog opštenja ili masmediji nesrećno odabran izraz. ${ }^{4}$ Terminološki problem u vezi s terminom masovna kultura razjašnjava Kelner koji, preuzimajući stav Vilijamsa (Raymond Williams) i članova birmingemske škole, ovaj termin smatra elitističkim, jer stvara binarnu opoziciju između klasične i nižerazredne kulture, prezrivo se odnoseći prema masama i njihovoj kulturi. ${ }^{5}$ Ovaj koncept je, po njegovom mišljenju, monolitan i homogen, i zbog toga neutralizuje kulturološke protivrječnosti i rastače suprotstavljena kretanja i grupe u neutralni koncept mase.

Maršal Makluan je o medijima pisao kao o čovjekovim produžecima, jer umjesto čovjeka vide i čuju. Pod uticajem medija, planeta je postala globalno selo zahvaljujući njihovoj sveprisutnosti i umreženosti. Baveći se formom (strukturom) opštila, ${ }^{6}$ a ne sadržajem (značenjem), svojim antropološkim pristupom, Makluan nam je omogućio da shvatimo da su sama tehnička sredstva poruke. Zbog prenaglašavanja značaja sredstva, dajući mu odlučujuću ulogu u razvitku ljudskog društva, MikašinovićGrujić smatra Makluana bliskim tehničkom hiperdeterminizmu, ${ }^{7}$ dok Veljanovski prihvata objašnjenje Levinsona (Paul Levinson), Makluanovog sljedbenika, da je Makluan mislio na uticaj koji određeni mediji proizvode na naše živote, i da je značaj tog

2 Janjetović Z., Od „Internacionale” do komercijale: popularna kultura u Jugoslaviji 1945-1991, Beograd 2011, str. 16. i 55.

3 Makluan M., Poznavanje opštila - čovekovih produžetaka, Beograd 1971, str. 109.

4 Šušnjić Đ., Ribari ljudskih duša: ideja manipulacije i manipulacija idejama, Beograd 2004, str. 108.

5 Kelner D., op. cit., str. 59.

6 Šušnjić Đ., op. cit., str. 111-112.

7 Mikašinović Grujić R., Homogenizacija društva kao posledica dejstva televizije, Kultura br. 35, Beograd 1976, str. 89. 
procesa toliko veliki i kompleksan da često prevazilazi svaku pojedinačnu kritiku. ${ }^{8}$

Prihvatajući Makluanov osnovni stav da je opštilo poruka, Šušnjić se ne slaže u pogledu značaja i značenja poruke u strukturi ostalih elemenata komunikacije, ${ }^{9}$ te smatra da Makluan griješi bar u dvije važne stvari: a) kad bi forma opštila bila važnija od sadržine opštila, onda bi cenzura osnovnu pažnju usmjerila na opštilo kao takvo, a ne na njihovu sadržinu; b) ako opštilo ne zastupa neku tačku gledišta već je samo usmjereno na proces sudjelovanja, kako to da ljudi biraju i opštila i sadržaje baš u skladu sa svojom tačkom gledišta. ${ }^{10}$ Isključivši kao beznačajan sadržaj poruke, nastavlja Šušnjić, Makluan isključuje i odašiljače, te na taj način odbacuje ideju da se medij može koristiti u svrhu dobra i zla. U Ribarima ljudskih duša Šušnjić se upravo bavi idejom manipulacije i manipulacijom idejama u masovnim medijima, jer smatra da je posredan način opštenja među ljudima radikalna promjena koja je publiku pretvorila u masu. ${ }^{11}$ Zato mas-medije treba posmatrati u određenom sistemu vlasništva i društveno-političke kontrole, jer u mjeri u kojoj su mas-mediji zavisni od države ili partije, u toj istoj mjeri služe kao sredstva za ekonomsku i političku propagandu, a ne kao sredstva za obrazovanje i vaspitanje, ${ }^{12}$ što je osnova na kojoj se zasniva i ovo istraživanje.

Nesavršena i nedovoljno razvijena kakva je bila, jugoslovenska štampa je, baš kao i kino, radio i TV-mreža, omogućila velikom dijelu jugoslovenskog stanovništva da uživa u popularnoj kulturi i postane dio nacionalne i internacionalne zajednice njenih potrošača. ${ }^{13}$ Kakva je bila medijska kultura i koliko su se stanovnici ruralne mikrozajednice u Đurčićima 1945-1991. integrisali u odnosu na globalne tokove u socijalističkoj državi, a time i u Makluanovo globalno selo, predmet je ovoga istraživanja.

\section{Štampa: knjige, novine, časopisi}

Proučavanje početaka evropske masovne kulture u štampi pokazuje da ona od sredine XVI vijeka postaje fundamentalni instrument popularne kulture. ${ }^{14}$ Još kod konzumatora drvoreznih plakata, koji su bili uglavnom nepismeni, Matić

8 Veljanovski R., Javni RTV servis u službi građana, Beograd 2005, str. 44.

9 Šušnjić Đ., op. cit., str. 110.

10 Ibid., str. 110.

11 Ibid., str. 51.

12 Ibid., str. 108-109.

13 Janjetović Z., op. cit., str. 85.

14 Matić M., Počeci popularne kulture, Kultura br. 125, Beograd 2009, str. 27. 
BORISLAVA VUČKOVIĆ

identifikuje instituciju zajedničkog čitanja, koju nalazim i kod stanovnika Đurčića na početku posmatranog perioda u vezi sa štampom.

Institucija zajedničkog čitanja štampanih knjiga ${ }^{15}$ u Đurčićima, neposredno poslije Drugog svjetskog rata, ukazuje na nizak nivo pismenosti stanovnika mikrozajednice, što potvrđuju i statistički podaci prvog poslijeratnog popisa stanovništva iz 1948. godine. Od tadašnjih ukupno 198 stalnih stanovnika od 10 i više godina, 92 je nepismeno, ${ }^{16}$ što je više od $46,6 \%$ i daleko je ispod prosjeka tadašnje NRH od $12,7 \%,{ }^{17}$ pa čak i prosjeka pismenosti Srba $(21,1 \%)^{18}$. Pismenost je u Đurčićima i rodno muški obilježena, jer je 35,89\% muških nepismeno i čak 53,33\% ženskih osoba, što je poznato i stanovnicima sela, koji precizno identifikuju muškarce kao nosioce pismenosti. Među rijetkim pismenim ženama pominju Simicu (rođ. Ojkić) Vučković, porijeklom iz Voćina, i mlađu od nje Cvijetu Vučković, porijeklom iz Čačinaca. Obje potiču iz geografski i populaciono manje marginalizovanih mjesta, što bi mogao biti faktor koji je uticao na njihovu pismenost.

Zajedničko čitanje štampanih knjiga u Đurčićima podsjeća na izvođenje i recepciju djela srpske narodne usmene književnosti, koja se takođe odvija tokom kolektivnog čina čitanja. I recepcija knjige i djelâ usmene književnosti se događaju u okviru porodično-rodbinsko-komšijskog kolektiva, kada prisustvuju svi članovi zajednice, bez generacijskih ili rodnih ograničenja. $\mathrm{Na}$ taj način u okviru kolektiva dolazi do stvaranja trajnih i prenosivih dispozicija za odnos prema svakom novom mediju - habitus medijske kulture. Pri tome dolazi do očuvanje ,integrativne porodične i prijateljske funkcije"19, koja će pratiti i potonje medije u Đurčićima.

Čini se da je Stogodišnjak prva popularna knjiga koja se usmenim putem prenosi u Đurčićima poslije Drugog svjetskog rata, čijih se fragmenata svjedoci sjećaju, a tu su i romani $u$

15 Sonders D., Izdavaštvo knjiga kao industrija, u: Uvod u studije medija, priredili Brigs A. i Kobli P., Beograd 2005, str. 43: Autor prenosi da je Unesko 1964. definisao „knjigu” kao „štampanu publikaciju, koja se ne izdaje periodično i koja sadrži najmanje 49 strana izuzimajući korice".

16 Konačni rezultati popisa stanovništva od 15. marta 1948. godine, knjiga V, Beograd 1955, str. 221. Od ukupno 78 muških, nepismeno je $28(35,8 \%)$; od ukupno 120 ženskih osoba, 64 su nepismene (53,3\%).

17 Ibid., str. 22: Nepismenih muških je 7,3\%, a ženskih 17,4\%.

18 Ibid., str. 22: Od ukupno 257056 Srba u NRH, nepismeno je 27285 (10,6\%); od ukupno 286739 Srpkinja, nepismeno je 87568 (30,5\%). Dakle, od ukupno 543795 Srba oba pola, nepismeno je 114853 (21\%).

19 Dragićević Šešić M., Privatni život u vremenu televizije, u: Privatni život kod Srba u dvadesetom veku, priredio Ristović M., Beograd 2007, str. 757. 
nastavcima. Među najstarijim knjigama svjedoci pominju Sveto pismo i srpske epske narodne pjesme, čijim izborom njihovi vlasnici iskazuju i potvrđuju vjerski pravoslavni i srpski nacionalni identitet. Knjige o Drugom svjetskom ratu, kao što su one o XII slavonskoj udarnoj brigadi i druge partizanske knjige, čitaju i posjeduju muškarci. Mnogi od njih su i sami bili partizani, čime potvrđuju svoj identitet partizanskih boraca, kao i nacionalni i vjerski identitet, jer su nosioci NOB-a u Slavoniji za vrijeme NDH bili upravo pravoslavni Srbi. Primjerak knjige Milutina Vujovića Mećavina brigada, takođe s ratnom temom, memorabilija je koju je unuk Srdije (Matija) Kokića ponio u izbjeglištvo u Srbiju, čime knjiga čuva sjećanje na pretka i njegov partizanski ratnički identitet, kojim i potomstvo potvrđuje postojanja određenog habitusa vezanog za ratni period.

I čitanje periodičnih novinskih izdanja u Đurčićima, čiji su redovni čitaoci u prvom periodu zahvaljujući svojoj pismenosti bili muškarci, uklapa se u instituciju zajedničkog čitanja. Štampane novosti Đurčani čitaju i usmeno prenose jedni drugima, a senzacionalističkih se neki sjećaju i danas. Cilj senzacija je, smatra Burdije (Pierre Bourdieu), da politički život učine besmislenim i ispraznim, da depolitizuju i svedu život društva na anegdotu ili obično naklapanje. ${ }^{20}$ Senzacionalne novosti uvijek su izazivale strah ili odbojnost kod obrazovanih čitalaca, ${ }^{21}$ te se i u primjeru nekih članova ove mikrozajednice može uočiti korelacija između niskog nivoa pismenosti i obrazovanja, i praćenja ovakvih vijesti.

U početku istraživanog perioda Đurčanima poštar periodično donosi dnevni list Borbu, jer u selu nema trafike na kojoj bi stanovnici mogli kupiti novine, duvan i časopise, što je dominantan način prodaje štampanih novinskih izdanja i karakterističan u cijeloj Evropi. ${ }^{22}$ Činjenica da u selu nema trafike je detalj koji potvrđuje marginalnost geografskog položaja sela, ali i depopulacijski trend. Iako je broj pismenih stanovnika u porastu tokom poslijeratnih decenija, što bi logično dovelo do komercijalnog povećanja uspješne prodaje štampanih novinskih izdanja, ipak u selu nema trafike, jer ukupan broj stanovnika ne raste.

Istovremeno, korišćenje poštanske mreže, radi prodaje štampanih novinskih izdanja, potvrđuje da i stanovnici ovoga

20 Burdije P., Narcisovo ogledalo: rasprava o televizijskom novinarstvu, Beo$\operatorname{grad} 2000$, str. 72.

21 Ibid., str. 63.

22 Brejtvejt B., Police pretrpane časopisima, u: Uvod u studije medija, priredili Brigs A. i Kobli P., Beograd 2005, str. 168. 


\section{BORISLAVA VUČKOVIĆ}

sela pripadaju klijenteli štampanih izdanja. Premda se polje $e^{23}$ novinarstva organizuje prema strukturi istovjetnoj onoj u drugim poljima, značaj komercijalnog kriterijuma je ovdje mnogo veći: polje novinarstva je neprestano podvrgnuto mjerama tržišta, i to ili kroz direktnu potvrdu klijentele ili kroz indirektnu potvrdu kriterijuma nivoa gledanosti. ${ }^{24}$ Smatra se da navika pretplate i sistem dostave štampe na kućnu adresu praktično u Jugoslaviji nije postojala, ${ }^{25}$ ali primjer ove ruralne zajednice to opovrgava. Nije zanemariva činjenica da je Borba bila direktivni partijski list, ${ }^{26}$ što bi pojasnilo zašto upravo ovo novinsko izdanje stiže na udaljene planinske kućne adrese pretplatnika ove zajednice, jer upravo su masovni mediji, pa i pisana riječ, zavisni od države ili partije u mjeri u kojoj služe kao sredstva za ekonomsku i političku propagandu, a ne kao sredstva za obrazovanje i vaspitanje. ${ }^{27}$

Da novine sa svojim karakteristično uopštenim čitateljstvom ne mogu zauzeti mjesto časopisa sa ciljnom publikom, kao što ni elektronski mediji ne mogu uništiti štampanu riječ, ${ }^{28}$ potvrđuje se i u Đurčićima time što neki od stanovnika redovno kupuju i čitaju časopise. Jedan od takvih specijalističkih ${ }^{29}$ naslova je časopis za lovce, namijenjen čitaocima s posebnim interesovanjima. Ovaj časopis primaju članovi Lovačkog saveza u okviru članarine. Od svih tradicionalnih starih medija, časopisi imaju najveću sposobnost da formiraju zajednicu istomišljenika, te je industrija časopisa više fragmentirana od drugih medija. ${ }^{30}$ Ako se prihvati stav da su časopisi životni stil i da za jedan časopis mora biti izvjesno da projektuje pozitivan životni stil, ${ }^{31}$ onda muškarac koji čita časopis specijalizovan za lovce iskazuje i potvrđuje svoj životni stil - lovca. Ovaj društveno kvalifikovani znak lovea proizvod je habitusa, koji spoznaje razlike u položaju prema određenim principima razlikovanja koji su, pošto su i sami proizvod tih razlika, objektivno usklađeni s njima i

23 Burdije P., op. cit., str. 96.

24 Ibid., str. 97.

25 Janjetović Z., Od „Internacionale” do komercijale: popularna kultura u Jugoslaviji 1945-1991, Beograd 2011, str. 83-84.

26 Ibid., str. 33.

27 Šušnjić Đ., Ribari ljudskih duša: ideja manipulacije i manipulacija idejama, Beograd 2004, str. 109.

28 Brejtvejt B., op. cit., str. 181.

29 Ibid., str. 158.

30 Barvajz P. i Gordon D., Ekonomija i mediji, u: Uvod u studije medija, priredili Brigs A. i Kobli P., Beograd 2005, str. 329.

31 Brejtvejt B., op. cit., str. 175. 
teže samim tim da ih opažaju kao prirodne..$^{32}$ Tako se čini da je prirodno da su samo muškarci lovci, koji na taj način iskazuju i potvrđuju svoj ekonomski i kulturni kapital, kao i muški rodni identitet.

Specijalistički naslov koji u Đurčićima čitaju je i Poljoprivredni kalendar, sa savjetima o organizovanju poljoprivredne proizvodnje i višegodišnjim kalendarom, čiji format odgovara današnjem formatu telefonskog imenika. Čitanjem ovoga izdanja, manje fragmentarnog od lovačkog časopisa pošto se gotovo svi članovi mikrozajednice bave poljoprivredom, stanovnici ove ruralne sredine potvrđuju kolektivni identitet radnog seljaštva. ${ }^{33}$

Povećanje broja pismenih u Đurčićima u korelaciji je s povećanjem broja knjiga u privatnim zbirkama koje stanovnici posjeduju. Sistemsko obrazovanje u socijalističkoj državi osnova je za povećanje broja školskih udžbenika, a kako su institucionalnim obrazovanjem obuhvaćena djeca oba pola, prvobitna dominacija muški rodno obilježene pismenosti u Đurčićima prestaje biti rodna privilegija, te i na mikronivou dolazi do potpune rodne ravnopravnosti pri opismenjavanju. Upravo poslijeratne generacije počinju kupovati knjiška izdanja sabranih djela domaćih ili stranih pisaca, kao što su Mir Jam ili F. M. Dostojevski. Povećanje broja knjiga u domaćinstvima $u$ vezi je s porastom ekonomskog kapitala stanovnika sela, a na platežno sposobnom čitateljstvu zavisi upravo industrija izdavaštva knjiga ${ }^{34}$. Književna djela bi vjerovatno našla nešto širi krug kupaca da knjiga tokom većeg dijela socijalističkog razdoblja nije bila srazmjerno skupa. ${ }^{35}$ Osim toga, izbor djelâ i pisaca, čije naslove u Đurčićima posjeduju, kazuje da u njihovom ukusu postoji odsustvo podjele na elitnu i nisku književnost. Posjedovanje izabranih ili sabranih djela Dostojevskoga, autora čiji se tekstovi kod nas smatraju bestselerima svih vremena, ${ }^{36}$ upućuje na uticaj dominantne kulture, i njenog prosvjetiteljsko-

32 Burdije P., Habitus i prostor stilova života, Kultura br. 109-112, I knjiga, Beograd 2005, str. 133.

33 Imširović J., Od staljinizma do samoupravnog nacionalizma: prilog kritici socijalizma u kongresnim dokumentima KPJ/SKJ V-VIII kongresa, Beograd 1991, str. 33-36.

34 Sonders D., op. cit., str. 51.

35 Janjetović Z., op. cit., str. 229.

36 Dragićević Šešić M., Oblici čitalačke recepcije, Kulturni život br. 7-8, Beograd 1987, str. 329. 


\section{BORISLAVA VUČKOVIĆ}

dogmatskog modela, ${ }^{37}$ koja u selo stiže preko školovanja, ${ }^{38}$ što potvrđuje činjenica da se ovakvi tekstovi nalaze u domovima u kojima žive pripadnici generacija koji nastavljaju školovanje i poslije završenog obaveznog osmogodišnjeg osnovnog obrazovanja. Knjiga je ne samo objekt i trgovačka roba, nego i subjekt kulture i nosilac vrijednosti, bilo institucionalnih ili ličnih, ne manje kada je u pitanju problem nacionalnog suvereniteta i identiteta, ${ }^{39}$ tako da se može reći da članovi ove mikrozajednice, čitanjem štampanih medija na srpskom jeziku, potvrđuju svoj nacionalni identitet.

U izboru popularnog štampanog štiva očite su rodne kulturne razlike. Djevojke u srednjoškolskom uzrastu kupuju i čitaju ljubavne romane, dok mladići čitaju kaubojske romane. Čitanje ljubavnih i kaubojskih popularnih romana je generacijski uslovljeno, a izborom žanra mladi potvrđuju svoje rodne identitete (ženski-ljubavni; muški-kaubojski), čime ne prevazilaze tradicionalne rodne podjele, već ih potvrđuju na tržištu popularne štampe.

Masovna kultura preuzima iz folklora stereotipe i univerzalizuje ih, čime se može objasniti i snaga i prodor masovne kulture $u$ tradicionalno kulturno zatvorene sredine, kakvima se smatraju seoske zajednice. ${ }^{40}$ Ljubić ima određene karakteristike narodne literature, ${ }^{41}$ te funkcioniše kao narodna bajka, a kaubojski roman kao junačka priča ili junačka epska pjesma. ${ }^{42}$ Zanimljiv je podatak da je ukupan tiraž roto romana u Jugoslaviji po naslovu bio 7,5 puta veći nego tiraži ostalih izdanja, a radilo se prvenstveno o romanima s ljubavnom, kaubojskom ili kriminalističkom tematikom, ${ }^{43}$ te se aktivnim čitanjem ovakvih izdanja mladi iz Đurčića uklapaju u opšte tokove u državi.

\section{Putujuće kino}

Tokom administrativnog sistema upravljanja kinematografijom u FNRJ (1945-1951), cjelokupna djelatnost bila je centralizovana; na čelu se nalazio Komitet za kinematografiju Vlade

37 Dragićević Šešić M., Neofolk kultura: publika i njene zvezde, Sremski Karlovci, Novi Sad 1994, str. 11-21.

38 Dragićević Šešić M., Seoska porodica na razmeđu tradicionalne i masovne kulture, u: Zbornik Matice srpske za društvene nauke br. 86-87, Novi Sad 1989, str. 45.

39 Sonders D., op. cit., str. 48.

40 Dragićević Šešić M., op. cit., str. 84.

41 Ibid., str. 79-87.

42 Ibid., str. 85.

43 Janjetović Z., op. cit., str. 242. 
FNRJ. ${ }^{44}$ Radi nadzora nad kinematografijom, tj. brige da samo ideološki ispravni filmovi stižu pred domaće gledaoce, 7. avgusta 1945. donijeta je Uredba o cenzuri kinematografskih filmova, ${ }^{45} \mathrm{i}$ institucija cenzure je postojala do $1971 .{ }^{46}$ Agitprop kultura je u Jugoslaviji trajala od 1945 do 1952. godine i Todić je dovodi u vezu sa staljinističkom erom. ${ }^{47}$ Poslije završetka rata KPJ je osnovala aparat za agitaciju i propagandu, čiji su zadaci bili raznovrsni. Partija je nastojala kreirati novu političku kulturu i novog čovjeka, čiji su karakter, ponašanje i shvatanje trebali odgovarati zahtjevima nove ideologije. ${ }^{48}$ Kako je jugoslovenski socijalizam bio sistem monističkog partijskog etatizma ${ }^{49}$, jednopartijski sistem ${ }^{50}$, monolitni politički sistem ${ }^{51}$, jasno je zašto metajezik agitacije i propagande trajno ostaje dio ideološkog monopola komunističke partije. ${ }^{52}$ Todić ga povezuje s koncepcijom staljinističke kulture, uspostavljenoj na čitavom kulturnom prostoru iza gvozdene zavjese. Ona u njemu prepoznaje totalizirajući kulturni trend, kakva je i globalizacija, jer se radi o presađivanju i nametanju gotovih modela ponašanja, bez obzira na specifičnost zatečenog kulturnog ambijenta, kao i poništavanju prostornih i vremenskih razlika. Medijima masovnih komunikacija, piše autorka, bilo je dozvoljeno samo propagiranje revolucionarne ideologije komunizma, tako da se od fotografije i filma očekivalo - reklamiranje partijske ideologije (moj kurziv). Cjelokupna kulturna aktivnost je stavljena pod rukovodstvo Agitpropa koji je imao svoje organe na svim nivoima partijske organizacije ${ }^{53}$ što potvrđuje i ovo istraživanje na mikronivou.

44 Kosanović D., Film i kinematografija (1896-1993), 08.08.2011, http://www. rastko.rs/isk/isk_27.html

45 Janjetović Z., op. cit., str. 176. i 178.

46 Ibid., str. 178: Tada je obaveza ocjenjivanja filmova koji će biti prikazani prenijeta na filmske proizvođačke i distributerske kuće.

47 Todić M., Fotografija i propaganda, 05.03.2011, http://www.photopropaganda.com/predgovor.php

48 Radić R., Srpsko društvo u 20. veku između dve vere: privatno i javno, u: Privatni život kod Srba u dvadesetom veku, priredio Ristović M., Beograd 2007, str. 667-668.

49 Imširović J., op. cit., str. 22.

50 Ilić J., Broj i razmeštaj Srba na teritoriji avnojske Hrvatske, u: Srbi u Hrvatskoj: naseljavanje, broj i teritorijalni razmeštaj, priredio Rudić V., Beograd 1993, str. 69.

51 Petranović B., Jugoslovensko iskustvo srpske nacionalne integracije, Beograd 1993, str. 105.

52 Todić M., Vek reklame, u: Kupite nešto i ovde, urednik Petrović G., Beograd 2010.

53 Janjetović Z., Od „Internacionale” do komercijale: popularna kultura u Jugoslaviji 1945-1991, Beograd 2011, str. 21. 


\section{BORISLAVA VUČKOVIĆ}

Zahvaljujući Putujućem narodnom kinu koje uspostavlja Agitprop Kotarskog odbora Narodne fronte krajem 1944, ${ }^{54}$ i Đurčani prate filmske predstave u svome selu: prvo u otvorenom prostoru jednog dvorišta, a kasnije u zatvorenom prostoru seoskog doma. Jasno je da svi masovni mediji nude ideologiju i gotove modele ponašanja, ${ }^{55}$ ali ostaje otvoreno pitanje kako se u novu ideologiju socijalizma i izgradnju novog čovjeka (i žene) uklapaju filmovi holivudske produkcije, s najzapadnijeg Zapada oličenog u SAD-u, ${ }^{56}$ koji se prikazuju u Đurčićima? Naime, prema svjedočanstvima bi Tarzan $i$ žena lovac mogao biti prvi film čiju su organizovanu projekciju na otvorenom Đurčani pratili na platnu raspetom na post'lli u dvorištu Petra (Pavle) Vučkovića 1952. ili 1953. godine.

Početkom pedesetih godina došlo je do oštrog zaokreta u spoljnoj politici, što je dovelo i do kopernikanskog obrta u kulturi. ${ }^{57}$ Porast životnog standarda do koga je postepeno došlo, a koji je dijelom bio uslovljen i promjenom u spoljnopolitičkoj orijentaciji, omogućio je i prelazak s masovne komunističke kulture za narod na popularnu kulturu, sličnu onoj koja je počela prevladavati u razvijenim zemljama Zapada, objašnjava Janjetović. Ovo je potvrda da i na mikronivou dolazi do pluralizma $u$ kulturi, a ne više pukog kopiranja sovjetskih uzora. Do prestanka uvoza sovjetskih filmova dolazi 1950, a definitivni zaokret u jugoslovenskoj kulturnoj politici i ofanzivna politika prema SSSR-u u vezi je s pojačanom podrškom sa Zapada i izborom Jugoslavije u Savjet bezbjednosti UN. ${ }^{58}$ Od 1952. godine, Jugoslavija je počela dobijati od SAD-a novac u sklopu Tehničke pomoći za nabavku filmova. ${ }^{59}$ Iste godine je Jugoslavija pristupila američkom programu (Information Media Guaranty Program) koji joj je omogućavao uvoz knjiga i filmova po vrlo povoljnom kursu. Ovo će američke filmove učiniti jeftinijim i zato konkurentnijim na jugoslovenskom tržištu od filmova iz drugih zemalja, pa i domaćih. Međutim, filmovi koji su kritički govorili o američkom društvu (Odavde do vječnosti, Na dokovima Njujorka, Buntovnik bez razloga, Ženski zatvor i drugi) nisu se mogli kupiti za prikazivanje u Jugoslaviji ni slobodnim devizama, nezavisnim od Tehničke pomoći, jer su Američka

\footnotetext{
54 Baćani T., Kulturna djelatnost, u: Podravsko-slatinski kraj: zbornik u povodu proslave četrdesetogodišnjice narodnog ustanka i socijalističke revolucijevođenog pod rukovodstvom Komunističke partije Jugoslavije i druga Tita, urednik Baćani T., Podravska Slatina 1982, str. 386-387.

55 Todić M., op. cit., str. 88.

56 Janjetović Z., op. cit., str. 45.

57 Ibid., str. 28.

58 Ibid., str. 41-43.

59 Ibid., str. 180.
} 


\section{BORISLAVA VUČKOVIĆ}

informativna agencija (United States Information Agency), odnosno Stejt department (State Department) to zabranjivali. ${ }^{60}$ Distributeri su najradije kupovali filmove na osnovu njihovog komercijalnog potencijala, pa se tako u najvećem broju slučajeva radilo o američkim vesternima, revijama i kriminalističkim i filmovima o Tarzanu. ${ }^{61}$

Prikazivanje holivudskog filma Tarzan $i$ žena lovac u Đurčićima posljedica je složenih procesa koji su se događali na političkoj i ekonomskoj sceni socijalističke Jugoslavije, ali i potvrda da su se globalni tokovi u državi odražavali i na kulturnom planu sve do ove geografski, ekonomski, politički i socijalno marginalne i marginalizovane zajednice.

Javna projekcija filma o Tarzanu u dvorištu domaćinstva Vučkovića potvrđuje tezu da u porodičnom domu dolazi do prožimanja njegove privatne i javne namjene, ${ }^{62}$ pri čemu porodica potvrđuje i učvršćuje društveni status u zajednici u kojoj živi, ${ }^{63}$ u ovom primjeru zahvaljujući odgovarajućoj građevini koju posjeduje. Ruralna fasada post'lje prestaje biti zid i granica, te postaje moderna optička refleksivna površina na kojoj teče kinematografska predstava, na isti način na koji su u gradu heterogene reklamne slike, sjajni veliki izlozi i ogromni elektronski ekrani agresivno poništili zid, tu granicu između stvarnosti i iluzije, života i reklame. ${ }^{64}$ Projekciji ovog filma prisustvuju djeca, mladi i stari, muškarci i žene, sjedeći na stolicama ili na tlu, i prate zvučni crno-bijeli film na njima nepoznatom jeziku kojim govore glumci. Ono što razlikuje štampane od filmskog medija, i potvrđuje upravo prikazivanje ovog filma, jeste da za praćenje filma nije neophodno da osoba bude pismena. Odatle ogromna popularnost komercijalnog filma, ${ }^{65} \mathrm{za}$ razliku od štampanih medija.

Odlazak u bioskop ima izrazito socijalni smisao, ${ }^{66} \mathrm{a}$ u seoskoj mikrozajednici Đurčića prisustvovanje članova zajednice kinematografskim projekcijama ima integrativnu funkciju.

60 Kosanović D., op. cit.

61 Janjetović Z., op. cit., str. 182.

62 Timotijević M., Rađanje moderne privatnosti: privatni život Srba $u$ Habzburškoj monarhiji od kraja 17. do početka 19. veka, Beograd 2006, str. 533.

63 Ibid., str. 531.

64 Todić M., op. cit., str. 74.

65 Jekel E., Kinematografija u Evropi, u: Uvod u studije medija, priredili Brigs A. i Kobli P., Beograd 2005, str. 228.

66 Dragićević Šešić M., Seoska porodica na razmeđu tradicionalne i masovne kulture, u: Zbornik Matice srpske za društvene nauke br. 86-87, Novi Sad 1989 , str. 82. 


\section{BORISLAVA VUČKOVIĆ}

Projekcijama se prisustvuje porodično, komšijski, rodbinski, tako da u okviru seoskog kolektiva dolazi do stvaranja habitusa vezanog za kinematografski medij. Svjedoci rođeni 1950-ih i ranih 1960-ih pamte da kino dolazi iz P. Slatine u određenim periodima, te da se u seoskom domu prikazuju i domaći tonski filmovi, koje gledaju i djeca i odrasli. Kao i u svakoj bioskopskoj dvorani, i filmski gledaoci u Đurčićima plaćaju ulaznicu kako bi pratili ratne filmove ili kaubojske, kao što je, na primjer, američki film Sto pušaka ili filmovi s temom meksičke revolucije - popularni komercijalni proizvodi američke filmske industrije.

Đurčani rado gledaju filmove i u svome selu i u drugim selima, kao što se rado i fotografišu, što znači da bez predrasuda prihvataju nove medije. Poslije izgradnje seoskog doma, mnoge generacije Đurčana odlaze na kino projekcije u dom, čime ovaj zatvoreni javni prostor dobija i novu ulogu bioskopske dvorane. U početku u seoskom domu prije filma ide žurnal, propagandni film, ${ }^{67}$ a potom Đurčani gledaju i ratne filmove $u$ kojima smo mi pobjeđivali. Svjedoci se ne sjećaju sadržaja filmskih žurnala, ali bi se moglo pretpostaviti da su imali mogućnost da prate domaće žurnale, pošto od kraja Drugog svetskog rata (1945) u Srbiji bez prekida teče proizvodnja filmskih žurnala i dokumentarnih filmova ${ }^{68}$. Žurnal i ratni filmovi ideološki se uklapaju u okvire ideološkog monopola Komunističke partije, a stanovnici Đurčića, prihvatanjem kinematografskih predstava s ovakvim sadržajima, uklapaju se u poželjni obrazac socijalističkog čovjeka, čiji korijen jeste u tome što pripadaju pobjednicima u Drugom svjetskom ratu.

\section{Radio}

Radio je najstariji elektronski masovni medij, koji u Britaniji počinje s BBC-jevim emitovanjem 1922. ${ }^{69}$ Nazivaju ga nevidljivi medij ${ }^{70}$, nevizuelni ili slijepi medij, ${ }^{71}$ jer mu nedostaju ne samo slike koje pružaju televizija ili bioskop već i vizuelni simboli štampe, tako da ljudi obično rade nešto drugo dok slušaju radio: oblače se, voze, rade, peru sudove. ${ }^{72} \mathrm{U}$ Đurčićima radio prvi put

67 Janjetović Z., op. cit., str. 33.

68 Kosanović D., Film i kinematografija (1896-1993), 08.08.2011, http://www. rastko.rs/isk/isk_27.html

69 Barvajz P. i Gordon D., Ekonomija i mediji, u: Uvod u studije medija, priredili Brigs A. i Kobli P., Beograd 2005, str. 322.

70 Brigs A. i Kobli P., Šta su mediji: uvod, u: Uvod u studije medija, priredili Brigs A. i Kobli P., Beograd 2005, str. 21.

71 Krizel E., Radio: javni servis, komercijalizacija i paradoksi izbora, u: Uvod u studije medija, priredili Brigs A. i Kobli P., Beograd 2005, str. 190.

72 Barvajz P. i Gordon D., op. cit., str. 324. 
čuju u prvoj polovini 1950-ih, a prvi radio-aparat se pojavljuje slijedeće decenije.

Do prve komunikacije svojstvene radiodifuziji, a to je jedan prema mnoštvu, ${ }^{73} \mathrm{u}$ Đurčićima dolazi dok se gradi tvrdi put kroz selo, koji je završen 1954. Tom prilikom su Đurčani mogli slušati program iz ugrađenog radija u automobilu, kojim su službenici došli radi kontrolisanja izgradnje puta, kada je s radio-programa treštala pjesma $O p$, žica, žica, žica/ drma mi se kabanica. Činjenica da stanovnici Đurčića prvi kontakt s radijom imaju kroz emitovan muzički program potvrđuje revolucionarnost ${ }^{74}$ radija u pogledu zabave, koji unosi u domove ljudi muziku. Radoznalost koju pokazuju stanovnici u susretu s radijom potvrđuje njihovu otvorenost i prema ovom mediju, kakvu su već pokazali u susretu s filmom.

Prvi radio je u Đurčiće donio Čedomir (Ljuboja) Kokić 1961. iz Egipta, gdje je kao vojnik u sastavu jedinica UN proveo šest mjeseci. Pojava ovoga i drugog prijemnika samo nekoliko mjeseci kasnije pokazatelji su materijalnog stanja stanovnika sela, što, uz činjenicu da prvi radio radi na baterije i da je elektrifikacija u Đurčićima provedena tek 1965, ukazuje na usporenu modernizaciju sela, a time i njegovo marginalizovanje. Vlasti su bile svjesne da radio može doprijeti i u krajeve gdje ne stiže štampa, kao i do nepismenih, tako da su se trudile da pojačaju kapacitet radio-stanica i obezbijede dostupnost radija što većem broju ljudi. ${ }^{75}$ Zbog toga su se trudile da svako selo ima bar po jedan radio-aparat, kao i da njima budu opremljeni i domovi kulture, zadružni domovi, zgrade opština i druga mjesta javnog okupljanja, ${ }^{76}$ ali tu privilegiju stanovnici ovoga sela nisu uživali.

Program koji je dopirao iz toga prvoga bijeloga prijemnika, sjeća se njegov vlasnik, slušali su i porodično i kolektivno u njegovoj porodičnoj kući: pjesme, prijenos fudbalskih utakmica, politiku. Žene i mladi su voljeli slušati pjesme, dakle zabavni program, dok su stariji muškarci preferirali vijesti, čime slušanje i recepcija određenih žanrova radijskih programa pokazuje elemente starosne i rodne obojenosti.

Rad Stjuarta Hola (Stuart Hall) i njegovih saradnika sugeriše da je predstavljanje događaja u vijestima uvek podvrgnuto procesu primarnog definisanja, koji vrši onaj dio društva koji posjeduje

\footnotetext{
73 Ibid., str. 330.

74 Veljanovski R., Javni RTV servis u službi građana, Beograd 2005, str. 52.

75 Janjetović Z., Od „Internacionale” do komercijale: popularna kultura u Jugoslaviji 1945-1991, Beograd 2011, str. 66.

76 Ibid., str. 67.
} 


\section{BORISLAVA VUČKOVIĆ}

najveći politički i ekonomski uticaj (vladajuća klasa, u tradicionalnom smislu ovog pojma), ${ }^{77}$ koji u socijalističkoj Jugoslaviji ima KP. Ljudima na vlasti bili su najvažniji informativno-politički programi, preko kojih se stanovništvo politički indoktriniralo i usmjeravalo u željenom pravcu. ${ }^{78}$

Ovo istraživanje potvrđuje kako se i na mikronivou može pratiti programska raznovrsnost, karakteristika javnog servisa ${ }^{79}$ : od vijesti i muzike do specijalizovanih emisija. Tako Đurčani redovno slušaju poljoprivrednu emisiju, koju na lokalnoj Radio stanici Podravska Slatina, osnovanoj početkom $1969,{ }^{80}$ vodi novinar Mirko Džombić. Nasuprot tradicionalnom konceptu radiodifuzije (broadcasting), koji podrazumijeva isti program za svakog gledaoca, ${ }^{81}$ emitovanje ovog programa je ipak za gledaoce sa specifičnim interesovanjima, što podsjeća na ono što Barvajz (Patrick Barvajz) i Gordon (David Gordon) vezuju za televizijski medij (narrowcasting).

Samim masama stanovništva, zabava uz muziku bila je mnogo važnija: statistike pokazuju da su vijesti bile vrlo slušane, ali da nisu smatrane najvažnijim dijelom programa, dok je čisto $k u l-$ turne sadržaje pratilo jako malo slušalaca, ${ }^{82}$ tako da su se, prema sjećanjima mojih svjedoka, i stanovnici ovoga sela uklapali u globalne tokove u socijalističkoj državi.

Radio se zajednički sluša u domovima u Đurčićima i u tome je njegova sličnost s institucijom zajedničkog čitanja ${ }^{83}$ kod štampanih medija ili zajedničkog gledanja filma. Ono po čemu se recepcija radijskog programa razlikuje od štampe, a vezuje $\mathrm{s}$ kinom, jeste naplaćivanje praćenja programa onima koji nisu članovi domaćinstva. Razlog za naplaćivanje mogao bi se objasniti činjenicom da građani direktno plaćaju pretplatu, ${ }^{84}$ tako da simboličnim novčanim iznosom gosti pomažu domaćinstvu u popunjavanju budžeta za radio-pretplatu.

Osim radio-aparata, Đurčani kasnije posjeduju i tranzistore. Tranzistor je bila nova tehnologija, koja je mogla garantovati preživljavanje ovog medija ${ }^{85}$ čiji se dolazak podudario $\mathrm{s}$

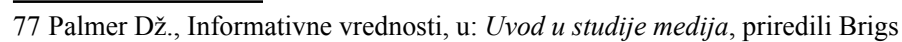
A. i Kobli P., Beograd 2005, str. 668.

78 Janjetović Z., op. cit., str. 67.

79 Veljanovski R., op. cit., str. 55.

80 Baćani T., op. cit., str. 388.

81 Barvajz P. i Gordon D., op. cit., str. 312.

82 Janjetović Z., op. cit., str. 68.

83 Matić M., Počeci popularne kulture, Kultura br. 125, Beograd 2009, str. 27.

84 Veljanovski R., op. cit., str. 70.

85 Krizel E., op. cit., str. 193-194. 
dolaskom rok muzike, ${ }^{86}$ jednog od žanrova popularne muzike. ${ }^{87}$ Dječaci na štaglju preko tranzistora slušaju program Radio stanice P. Slatina. Oni prate i emisiju Minimaks, koju je vodio Milovan Ilić Minimaks, jedan od prvih nekonvencionalnih voditelja u SFRJ, koji je pored klasične najave ubacivao viceve, doskočice i džinglove, te puštao rokenrol. Minimaks je bila jedna od prvih emisija u kojoj je bilo dosta zabavne muzike, a njegova krilatica iz najave emisije je bila minimum govora, maksimum muzike.

Popularna muzika je komercijalno proizvedena muzika za masovno tržište i sve do dolaska MTV-a (Music Television), sredinom osamdesetih godina prošloga vijeka, radio je neosporno bio najvažniji medij za potvrđivanje forme i sadržaja popularne muzike, ${ }^{88}$ što pokazuje i ovo istraživanje na mikronivou u jednoj socijalističkoj državi. Preko radio-talasa Đurčanima počinju stizati i proizvodi novokomponovane narodne pjesme ${ }^{89}$ ili nove narodne pesme ${ }^{90}$, najrašireniji oblik masovne kulture ${ }^{91} \mathrm{u}$ poslijeratnoj Jugoslaviji. Ove pjesme tipološki pripadaju novokomponovanom kulturnom modelu masovne kulture u socijalističkoj Jugoslaviji, smatra Dragićević Šešić, kojem pripadaju i članovi ruralne mikrozajednice Đurčana, i to bez starosnih ili rodnih ograničenja.

Osim novokomponovanog kulturnog modela, u Đurčićima postoji i prodor rok kulture kao kulture mladih, generacijski i muški rodno obilježene, tako da se ne može govoriti o homogenom kulturnom modelu. Pripadnici ove ruralne mikrozajednice konstruišu medijski identitet bez rodnih i starosnih barijera, $\mathrm{s}$ izuzetkom popularne rok muzike. Ova potkultura je generacijski i muški rodno obilježena, a njena veza s kulturom roditelja je u tome što je u odnosu subordinacije prema dominantnoj kulturi. Kako kulture uvijek postoje u odnosu dominacije i subordinacije, prema mišljenju Klarka (John Clarke), Hola, Džefersona (Tony Jefferson) i Robertsa (Brian Roberts), ${ }^{92}$ onda potkulture mladih (mods, tediboj, roker, skinhed, bitnik) imaju

86 Ibid., str. 194.

87 Šuker R., Marketing i medijacija popularne muzike, u: Uvod u studije medija, priredili Brigs A. i Kobli P., Beograd 2005, str. 254.

88 Ibid., str. 254. i 264.

89 Golemović O. D., Čovek kao muzičko biće, Beograd 2006, str. 245.

90 Čolović I., Nove narodne pesme, Kultura br. 57-58, Beograd 1982, str. 2955.

91 Dragićević Šešić M., Neofolk kultura: publika i njene zvezde, Sremski Karlovci, Novi Sad 1994, str. 11-21.

92 Clarke J., Hall S., Jefferson T. i Roberts B., Subcultures, cultures and class, in: Resistance Through Rituals - Youth Subcultures in Post-war Britain, eds. Hall S. i Jefferson T., London, New York 2006. 


\section{BORISLAVA VUČKOVIĆ}

dvostruku artikulaciju: prema kulturi roditelja (,'parent' culture", npr. radničke klase) i prema dominantnoj kulturi. Potkulture su važne zato što odgovor mladih ima naročito opipljivu formu, pri čemu mladi iz određene klase reprodukuju poziciju roditeljske klase kojoj pripadaju. Prodor rok potkulture sa Zapada u jugoslovensko komunističko-socijalističko društvo odvija se upravo preko mladih, kako na globalnom nivou, tako i na mikronivou zajednice u Đurčićima. Ni novokomponovani kulturni model niti rok model ne pripadaju dominantnom kulturnom modelu u Jugoslaviji (koji čine prosvjetiteljsko-dogmatski model i elitna kultura), što znači da su pripadnici mikrozajednice u Đurčićima izborili kulturni prostor u odnosu na dominantnu kulturu i s njim u vezi pribavili i određeni kulturni kapital, u čijem okviru se pojavljuje i potkulturni kapital mladih u vezi $\mathrm{s}$ rok muzikom/potkulturom. Time bi se oba ova modela mogla smatrati primjerima otpora dominantnoj kulturi. Da li je onda televizija bila prva socijalistička institucija koja je potvrdila pravo na razlikovanje mladih, kao i pravo na praćenje zapadnih standarda zabave u svim područjima, kako smatra Dragićević Šešić, ${ }^{33}$ ili je to, prema istraživanju u ovoj ruralnoj zajednici, već uradio radio?!

Dominacija novokomponovanog kulturnog modela i novokomponovane narodne pjesme, kao najraširenijeg oblika masovne kulture u socijalističkoj Jugoslaviji, potvrđuje primat nacionalnog repertoara, muzike koju izvode muzičari koji žive u određenoj zemlji, u odnosu na lingvistički imperijalizam engleskog ${ }^{94}$ čija pojava je u vezi s dolaskom rok muzike na radio-talasima.

Sa stanovišta društveno-istorijskih okolnosti, važno je uočiti da razvoj radija napreduje poslije Prvog, a televizije poslije Drugog svjetskog rata. ${ }^{95}$ Veljanovski smatra da nema nikakve sumnje da su strateški i vojno-politički interesi raznih zemalja i te kako pospješili istraživanja, razvoj tehnologije i ulaganja u njeno usavršavanje. Televizija je počela preuzimati primat radiju u svjetskim razmjerima i nametati se kao najuticajniji medij. ${ }^{96}$ Od dolaska televizije, radio je postao sekundarni medij, ${ }^{97}$ ali je upravo radio postavio temelje u izgradnji potrošačkog društva i otvorio prostor za sve tehnološki nove i masovne medije: film,

\footnotetext{
93 Dragićević Šešić M., Privatni život u vremenu televizije, u: Privatni život kod Srba u dvadesetom veku, priredio Ristović M., Beograd 2007, str. 758.

94 Šuker R., op. cit., str. 259, 260.

95 Veljanovski R., Javni RTV servis u službi građana, Beograd 2005, str. 64.

96 Ibid., str. 151.

97 Barvajz P. i Gordon D., Ekonomija i mediji, u: Uvod u studije medija, priredili Brigs A. i Kobli P., Beograd 2005, str. 324.
} 
televiziju, internet, koji će sinhronizovano djelati u oblikovanju globalne potrošačke kulture, ${ }^{98}$ pod čijim uticajem su i članovi ruralne mikrozajednice u Đurčićima.

\section{Televizija}

Krunisanje britanskog kralja Džordža (George) VI bio je prvi događaj koji je prenosila televizija, odmah po osnivanju 1936. godine. ${ }^{99} \mathrm{U}$ to vrijeme televizijski program imale su samo četiri zemlje: Engleska, SAD, Sovjetski Savez i Francuska - 1937. godine. ${ }^{100}$ Drugi svjetski rat je zaustavio televiziju u Evropi, dok Amerika nije prekidala programe za vrijeme rata, a njemačka televizija doživljava procvat, koju Rajh koristi kao zabavu za vojnike. ${ }^{101}$

Narodni odbor je u Jugoslaviji tokom 1955. donio odluku da iz svojih sredstava pokrene rad na televiziji, ${ }^{102}$ i već 8 . jula 1956. SIV je donio odluku o izdvajanju sredstava za rad na televiziji u tri centra: Beogradu, Zagrebu i Ljubljani. ${ }^{103}$ Kapaciteti domaće industrije tada su iznosili samo 10.000 prijemnika godišnje. ${ }^{104}$ Godine 1961. cijene televizora su se kretale između 135.000 i 160.000 dinara, ${ }^{105}$ a njegova (ne)dostupnost jasna je ako se ima na umu da je prosječna radnička plata iznosila između 20.000 i 30.000 dinara. ${ }^{106}$ Statistički podaci pokazuju da je u razvijenim zemljama, gdje nije postojalo materijalno ograničenje za nabavku televizijskog aparata, gdje je na tržištu bilo dovoljno TV prijemnika i gdje je stanovništvo imalo dobru kupovnu moć, gotovo svako domaćinstvo u roku od deset godina nabavilo televizor. ${ }^{107}$

Televizija kao sredstvo masovnog komuniciranja prenosi informaciju i znanje masovnom auditorijumu i na taj način vrši homogenizaciju društva. ${ }^{108} \mathrm{U}$ proces ujednačavanja kulture Đurčani ulaze u jesen 1964, kada Joco (Jovo) Vučković donosi u

98 Todić M., Vek reklame, u: Kupite nešto i ovde, Todić M. i Pištalo V., Beograd 2010, str. 78.

99 Dragićević Šešić M., op. cit., str. 734.

100 Đukić A., Televizija, Beograd 2007, str. 30.

101 Ibid., str. 11.

102 Dragićević Šešić M., op. cit., str. 737.

103 Janjetović Z., Od „Internacionale” do komercijale: popularna kultura u Jugoslaviji 1945-1991, Beograd 2011, str. 69.

104 Dragićević Šešić M., op. cit., str. 746.

105 Janjetović Z., op. cit., str. 71.

106 Ibid., str. 76.

107 Mikašinović Grujić R., Homogenizacija društva kao posledica dejstva televizije, Kultura br. 35, Beograd 1976, str. 85.

108 Ibid., str. 79. 
selo prvi crno-bijeli televizijski aparat. Od toga trenutka televizijski aparati postaju dio kućnog inventara u domovima stanovnika ovoga sela, koji prihvatajući moderno doba onoliko koliko im ekonomske i kulturne mogućnosti to dozvoljavaju ${ }^{109}$ postaju i sami dio Makluanovog globalnog sela. Svjetsko selo je novi svijet koji su nova opštila (mediji), među njima posebno televizija, smanjili na veličinu sela, smatra Makluan. Trenutnost opticaja električnih obavještenja ne uvećava čovjekovu porodicu, već je uključuje u kohezivno stanje seoskog života, ${ }^{110}$ što ovaj autor povezuje s povratkom audio-taktilnoj kulturi i organskoj društvenoj zajednici.

Svako veče seljani dolaze u dom vlasnika televizijskog aparata kako bi pratili televizijski program. Dragićević Šešić je zapazila da televizijski medij, čija je svrha kreiranje javnog mnjenja, istovremeno duboko utiče i na način života u svakodnevici, od oblikovanja i uređenja stana, preko vremena i načina ručavanja, do prirode porodičnih i prijateljskih razgovora, ${ }^{111}$ što potvrđuje i ovo istraživanje. Privatni prostor kuhinje, u koji Đurčani smještaju televizijski prijemnik, ostaje centralno mjesto u kojem se sa članovima porodice i domaćinstva okupljaju komšije, rodbina i prijatelji radi zajedničkog gledanja televizijskog programa. Porodični dom još jednom potvrđuje svoju dvojnu strukturu, koja se ogleda u prožimanju njegove privatne i javne namjene, a porodica potvrđuje i učvršćuje društveni status u zajednici u kojoj živi. ${ }^{112}$

Pojavu prvih televizijskih aparata u Đurčićima prati stari obrazac plaćanja, koji vezuje televizijski i radijski program s kinom. Televizijska pretplata se uvodi 1960 -ih, ${ }^{113}$ tako da gledaoci u Đurčićima (neredovnim) plaćanjem pomažu dopunjavanju domaćinovog budžeta za televizijsku pretplatu, pri čemu naplaćuje samo vlasnikova supruga. Ovaj čin stoga ima žensko rodno obilježje, a prostor kuhinje u kojoj se nalazi televizijski aparat postaje ženski prostor u kome ona ima priliku da iskaže i potvrdi svoj

109 Gavrilović Lj., Odevanje između javnog i privatnog, u: Privatni život kod Srba u devetnaestom veku: od kraja osamnaestog veka do početka Prvog svetskog rata, priredili Stolić A. i Makuljević N., Beograd 2006, str. 423.

110 Makluan M., Poznavanje opštila - čovekovih produžetaka, Beograd 1971, str. $154 ; 414-415$.

111 Dragićević Šešić M., op. cit., str. 733.

112 Timotijević M., Rađanje moderne privatnosti: privatni život Srba u Habzburškoj monarhiji od kraja 17. do početka 19. veka, Beograd 2006, str. 533. i 531.

113 Đukić A., op. cit., str. 88. 
lični i rodni identitet, naglašavajući vlastitu ličnost, ${ }^{114}$ koja se vezuje upravo za moderno društvo. ${ }^{115}$

Aktivnost zajedničkog praćenja televizijskog programa u Đurčićima i televizijski aparat kao predmet vlasništva (potrošnja) čine sistematičan izraz oblika egzistencije stanovnika ove mikrozajednice - ono što se, prema Burdijeovom mišljenju, naziva životnim stilom.116 Različitim pozicijama u društvenom prostoru odgovaraju životni stilovi, sistemi diferencijalnih odstupanja koji su simbolički prevod objektivnih, egzistencijalnih razlika. (...) Ukus, sklonost i sposobnost za (materijalno i/ili simboličko) prisvajanje određene vrste predmeta ili delatnosti (razvrstanih po klasama, ili pak razvrstavajućih) jeste stvaralačka formula koja se nalazi u načelu životnog stila; to je jedinstven skup distinktivnih preferencija koje pokazuju, u specifičnoj logici svakog simboličkog potprostora - nameštaja, odeće, jezika ili telesnog držanja - istu izražajnu nameru, načelo jedinstva stila; ono se saznaje neposrednim opažanjem, dok ga analiza razara, izdvajajući u njemu posebne univerzume.117 Svojim životnim stilom u vezi s televizijskim medijem, stanovnici ove mikrozajednice se uklapaju u globalne tokove, posebno s obzirom na celokupnu ekonomsku nerazvijenost Jugoslavije118.

Kolektivno gledanje televizijskog programa u privatnom prostoru porodičnog doma, na početku razvoja televizije je reprezentativni način praćenja televizijskog programa, kako u ruralnom mikroprostoru Đurčića, tako i u gradskim sredinama, ali i u kapitalističkoj državi poput Britanije, gdje je porodično gledanje televizije (Family Viewing Policy) poznato od ranih šezdesetih godina prošloga vijeka. ${ }^{119}$ Suprotno ovakvom načinu praćenja, organizovana javna gledanja televizijskog prijenosa, poput Olimpijade 1936, u režiji njemačkog nacističkog režima, smatraju se nereprezentativnim za potonju institucionalizaciju medija (radija i televizije). ${ }^{120}$ Porodično gledanje televizije je u Đurčićima prošireno na članove mikrozajednice, prvenstveno

114 Todić M., Na ludom kamenu: fotografija i ceremonija građanskog venčanja u Srbiji 1850-1940, u: Na ludom kamenu: venčana fotografija u Srbiji 1850-1998, urednica Bjeladinović Jergić J., Beograd 2002.

115 Timotijević M., op. cit., str. 99.

116 Burdije P., Klasni ukusi i životni stilovi, u: Studije kulture: zbornik, priredila Đorđević J., Beograd 2008, str. 156.

117 Ibid., str. 156.

118 Janjetović Z., op. cit., str. 74: Autor daje primjer da je po broju televizora Jugoslavija 1963. još uvijek bila među posljednjim zemljama u Evropi.

119 Paterson R., Skica za analizu savremene televizije, u: Uvod u studije medija, priredili Brigs A. i Kobli P., Beograd 2005, str. 222.

120 Mik A., Benjamin, televizuelno i „fašistički subjekt”, Kultura br. 125, Beograd 2009, str. 36-37. 


\section{BORISLAVA VUČKOVIĆ}

na djecu i mlade kao njihove najčešće konzumente. Kolektivno porodično-komšijsko gledanje televizije poznato je i iz istraživanja drugih seoskih zajednica u Jugoslaviji, ${ }^{121} \mathrm{~s}$ tim što je ono u Đurčićima prošireno rodbinskim vezama, pošto su neki članovi u zajednici istovremeno i rođaci i komšije. Članovi ove mikrozajednice, kroz kolektivno gledanje televizije, iskazuju modernističku težnju za prihvatanjem novoga, kada istovremeno izražavaju i socijalnu koheziju grupe. Prihvatanje novog televizijskog medija potvrđuje Hobsbaumovu (Eric Hobsbawm) tezu da se u tradicionalnim društvima ne spriječavaju inovacije i promjene, mada moraju odgovarati ili biti identične s prethodnim obrascima. Taj obrazac je vezan za zajedničku, kolektivnu recepciju medija - i starih i novih. Recepcija medija u zajednici je običaj poznat članovima ove ruralne mikrozajednice još od starog štampanog medija (knjige, novine, časopisi), koji je omogućio da se novi mediji (film, radio, televizija) prihvate na osnovu starih obrazaca, čime se može potvrditi Hobsbaumova teza o fleksibilnosti tradicionalnih zajednica. ${ }^{122}$

Đurčani prvo zajedno čitaju knjige, novine i časopise, potom zajedno gledaju filmove, da bi kasnije takođe u okviru zajednice slušali radio, a na kraju pratili i televizijski program, što pojašnjava na koji način dolazi do stvaranja dispozicije (ili ukusa) u vezi s medijima. Recepciji medija u Đurčićima prisustvuju djeca i odrasli, muškarci i žene, što znači da ona nema polnu, rodnu, starosnu ni socijalnu stigmu. Kako u ovakvim situacijama postoji nadzor nad mladima i djecom, ovi prirodno u društvu odraslih usvajaju dispoziciju/ukus za medije, i jasnije je da od načina sticanja kulture zavise i dispozicije prema kulturi ${ }^{123}$. Ovakva medijska kultivisana dispozicija je dio sistema dispozicija, tj. habitusa, u kome se ogleda čitav društveni položaj. ${ }^{124}$ Zbog svog opšteg karaktera i mogućnosti prenošenja on stvara, objašnjava Burdije, preferencije koje su objektivno međusobno povezane, prenoseći svoje jedinstvo i svoj stil na vještinu življenja svakog pojedinog subjekta, a objektivnom orkestracijom i na sve subjekte koji su podvrgnuti istim operacijama obrade, tj. koji su proizvod istih životnih uslova.

121 Dragićević Šešić M., Seoska porodica na razmeđu tradicionalne i masovne kulture, u: Zbornik Matice srpske za društvene nauke br. 86-87, Novi Sad 1989, str. 82.

122 Hobsbom E., Uvod: kako se tradicije izmišljaju, u: Izmišljanje tradicije, priredili Hobsbom E. i Rejndžer T., Beograd 2002, str. 7.

123 Burdije P., Klasna funkcija umetnosti, Kultura br. 32, Beograd 1976, str. 100.

124 Ibid., str. 110. 


\section{BORISLAVA VUČKOVIĆ}

\section{Jedinstven medijski prostor u mikrosredini}

Poznato je da socijalistička Jugoslavija nije imala jedinstven sistem radio-televizije, već je u šest republika i dvije pokrajine postojalo osam radio-televizija koje su funkcionisale kao klasični državni mediji, objedinjeni, u određenoj mjeri, u udruženju, Jugoslovenskoj radio-televiziji (JRT). ${ }^{125}$ JRT je 1950. bila jedna od osnivača Evropske radiodifuzne unije (European Broadcasting Union), jedina iz neke socijalističke države među državama osnivačima. ${ }^{126}$

JRT funkcioniše kao javni servis. Javni servis se posmatra kao složeni sistem masovnog komuniciranja koji se po strukturi, funkcijama i značaju bitno razlikuje od ostalih javnih glasila. Organizacija javne službe nije jednostavno - medij. To je uvek konglomerat većeg broja medija, više programa radija i televizije koji kao komunikacioni kanali pružaju usluge građanima. ${ }^{127}$ Negrin (Ralf Negrin) smatra da je javni servis zapravo državni monopol na radiodifuziju, i to prirodni monopol, jer se vjeruje da ova struktura unaprijeđuje javni interes. ${ }^{128}$ Veljanovski samo državnim radio-televizijama vezanim za jednopartijske sisteme pripisuje ideološku, propagandnu matricu, ${ }^{129} \mathrm{~s}$ tim što o Jugoslaviji piše da je i u vrijeme socijalizma uspijevala u izvjesnoj mjeri oponašati praksu najrazvijenijih medijskih sistema javnog servisa u Evropi. ${ }^{130}$ Međutim, u mjeri u kojoj su mas-mediji zavisni od države ili partije, smatra Šušnjić, u toj istoj mjeri služe kao sredstva za ekonomsku i političku propagandu, a ne kao sredstva za obrazovanje i vaspitanje. ${ }^{131}$ Ako se mas-mediji posmatraju u određenom sistemu vlasništva i društveno-političke kontrole, ${ }^{132}$ onda propagandna matrica nije ekskluziva samo jednopartijskih sistema. To potvrđuje primjer britanske i francuske radio-televizije. Do 1955. BBC je bio u vlasništvu države i imao je monopol nad radiodifuzijom i održavao je jedan prilično staložen nacionalni TV servis i tri radio-servisa. ${ }^{133}$ Komercijalna

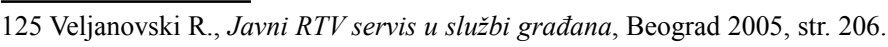
i 215 .

126 http://www.ebu.ch/en/about/index.php, 22. 07. 2011.

127 Veljanovski R., op. cit., str. 11.

128 Negrin R., Medijske institucije u Evropi, u: Uvod u studije medija, priredili Brigs A. i Kobli P., Beograd 2005, str. 358.

129 Veljanovski R., op. cit., str. 8.

130 Ibid., str. 10.

131 Šušnjić Đ., Ribari ljudskih duša: ideja manipulacije i manipulacija idejama, Beograd 2004, str. 108-109.

132 Ibid., str. 108-109.

133 Barvajz P. i Gordon D., Ekonomija i mediji, u: Uvod u studije medija, priredili Brigs A. i Kobli P., Beograd 2005, str. 316-317. 


\section{BORISLAVA VUČKOVIĆ}

televizija je u Britaniji uvedena 1955, ${ }^{134}$ ali je monopolski položaj BBC zadržao u radio-programu, i tek od 1973. godine Britanija ima i lokalnu privatnu radio-stanicu. ${ }^{135}$

Od početka kontinuiranog emitovanja do rastakanja Jugoslavije, televizijski program bio je zajednički jugoslovenski program, utemeljen na načelu da svaka televizijska stanica preuzima i programe drugih jugoslovenskih TV stanica. ${ }^{136}$ Po svom složenom sastavu i multikulturnom karakteru, piše Savićević, ovaj program bio je osoben u svijetu. Blagodareći njemu, srpski narod u drugim jugoslovenskim republikama mogao je pratiti programe Televizije Beograd koji su preuzimale republičke TV stanice; pa i kad je šezdesetih godina počelo zatvaranje kulturnih i informativnih prostora republika, mogao je biti posredstvom televizije u dodiru sa svojom kulturnom maticom. I Đurčani prate zajednički program JRT-a, nacionalnog radiodifuznog servisa Jugoslavije, te se sjećaju da su pratili program Radio-televizija Beograd i Zagreb. Njihovu pažnju su privlačili igrani program, vijesti, zabava - standardni televizijski žanrovi ${ }^{137}$. Proizvodnjom ovakvih žanrova televizija ispunjava jednu od funkcija javnog servisa, po kome je on promoter nacionalne kulture u svim audio-vizuelnim domenima, kako u sopstvenoj zemlji, tako i u inostranstvu. ${ }^{138}$ Televizija je neosporno vodeće sredstvo javne komunikacije, važan izvor saznanja i veliki izvor razonode i zabave (saznajna mašina i zabavna mašina). ${ }^{139}$ Paterson (Richard Patterson) objašnjava da upravo javne servise na kanalima koji se obraćaju širokoj publici karakteriše ravnoteža ukusa koje treba zadovoljiti - pokušaj da se zadovolji svaki gledalac u nekom vremenskom periodu u odnosu na cjelokupni program: da se on informiše, obrazuje ili zabavi. ${ }^{140}$

U Đurčićima se, kako pamte i naglašavaju svi svjedoci, obavezno pratila informativna emisija Dnevnik tokom čitavog perioda, što znači da je i na mikronivou ove zajednice televizija značajno sredstvo informisanja, ili čak vodeće sredstvo javne komunikacije u području informisanja, na kojem zastupljenost politike u televizijskim programima raste u skladu s rastom i u ostalim

134 Paterson R., op. cit., str. 211-210.

135 Veljanovski R., op. cit., str. 150.

136 Savićević M., Televizija, 08.08.2011, http://www.rastko.rs/isk/isk_29.html

137 Paterson R., op. cit., str. 224.

138 Veljanovski R., op. cit., str. 29.

139 Korner Dž., Televizija i kultura: obaveze i zadovoljstva, u: Britanske studije kulture: geografija, nacionalnost i identitet, priredili Morli D. i Robins K., Beograd 2003, str. 261.

140 Paterson R., op. cit., str. 224. 


\section{BORISLAVA VUČKOVIĆ}

zemljama Evrope. ${ }^{141}$ Do polovine sedamdesetih vijesti su imale večernji termin, a prvi popodnevni termin vijesti uspostavljen je 11. decembra 1974, da bi redovno emitovanje počelo 1. januara $1975 .^{142}$ Vijest neki autori posmatraju kao nešto što igra ključnu ulogu u ponudi nepristrasnih informacija građanima i što obezbjeđuje funkcionisanje demokratskih procesa. ${ }^{143}$ Međutim, Burdije je uvidio da ljude koji imaju obavezu da nas obaviještavaju informišu neki drugi informatori. ${ }^{144}$ Jasno je, piše on, da različite vlasti, posebno na nivou vlade, djeluju ne samo ekonomskim pritiscima, koje su one u mogućnosti da sprovode, već i svim drugim vrstama pritisaka koje monopol nad legitimnom informacijom opravdava - posebno monopol nad zvaničnim izvorima informacija. ${ }^{145}$ Taj monopol pruža vladi i administraciji, ali i pravnim, naučnim i drugim vlastima oružje u borbi s novinarima. Kroz tu borbu autoriteti pokušavaju manipulisati informacijama ili onima koji ih prenose, dok štampa sa svoje strane pokušava manipulisati posjednicima informacija; ona ih nastoji pridobiti i uz njihovu pomoć sebi obezbijediti ekskluzivnost. Ne treba zaboraviti ni izuzetnu simboličku moć koja najznačajnijim državnim autoritetima omogućava da upravo oni određuju, kroz svoje djelovanje, odluke i intervencije u polju novinarstva, dnevni red i hijerarhiju događaja koji će biti nametnuti raznim novinama, piše Burdije. Dakle različite vrste pritisaka i monopol nad zvaničnim izvorima informacija, kao i manipulisanje, obezbjeđuju različite vlasti kroz državni monopol nad medijima, pa i televizijskim, i ta moć obilježava oba sistema - i komunističkosocijalistički i kapitalistički.

Igrani program na televiziji predstavlja ogledalo i prozor u raznolikost društva i u većini zemalja igrani program lokalne proizvodnje privlači najširu publiku, ${ }^{146}$ te su serije svuda u svijetu privilegovani medijski artefakt za razumijevanje društvenih vrijednosti, nastojanja, ambicija. ${ }^{147}$ To potvrđuje i ovo istraživanje na mikronivou, jer i u Đurčićima prate komične serije domaće proizvodnje s Miodragom Petrovićem Čkaljom i Mijom Aleksićem, kao što su Kamiondžije. One se vikendom emituju

141 Đukić A., Televizija, Beograd 2007, str. 91-92.

142 Ibid., str. 257.

143 Paterson R., Skica za analizu savremene televizije, u: Uvod u studije medija, priredili Brigs A. i Kobli P., Beograd 2005, str. 224.

144 Burdije P., Narcisovo ogledalo: rasprava o televizijskom novinarstvu, Beograd 2000, str. 42.

145 Ibid., str. 95.

146 Paterson R., op. cit., str. 225.

147 Dragićević Šešić M., Privatni život u vremenu televizije, u: Privatni život kod Srba u dvadesetom veku, priredio Ristović M., Beograd 2007, str. 752753. 


\section{BORISLAVA VUČKOVIĆ}

u udarnom večernjem terminu, što potvrđuje njihovu popularnost na prostoru čitave zemlje, kao i uređivačku koncepciju koja prati ovakav program. Igrane serije nastaju na samom početku Televizije Beograd, u vidu humorističkih serija u zabavno-humorističkom programu. ${ }^{148} \mathrm{U}$ nizu godina, piše Savićević, najveće interesovanje gledalaca će privlačiti ne samo u Srbiji već i u svim sredinama nekadašnje Jugoslavije. Davaće humorističku i nerijetko satiričnu sliku naših ljudi i društva, u najboljim tradicijama srpskog humora, i sve više će postajati njegov glavni tok. Dramske serije nastaju kasnije, sedamdesetih godina - prvo kao televizijske adaptacije proznih dijela, najčešće romana i zbirki pripovijetki srpskih pisaca, a potom se pripremaju i biografske serije i serije različitih tema.

\section{Praznik i medijski spektakl}

Ako se uporede obrasci slavlja i proslava u seoskoj mikrozajednici Đurčića s istraživanjem privatnog života u urbanoj sredini Milene Dragićević Šešić, ${ }^{149}$ uočavaju se sličnost i razlika među njima. Fenomen slava, uprkos socijalističkom neprepoznavanju, činjenici da su ga i radio i televizija ignorisali, uspijevao je očuvati svoju integrativnu porodičnu i prijateljsku funkciju, ${ }^{150}$ u gradskoj kao i u seoskoj kulturnoj mikrozajednici u Đurčićima. S druge strane, dok su rođendanska slavlja, žurevi, proslave Nove godine, viđeni u serijama i filmovima, polako ulazili i postajali dio kulture u gradskom prostoru i ispunjavali znatno više svakodnevicu od tradicionalnih slavlja, u ovoj ruralnoj mikrozajednici do ovakvog uticaja ne dolazi. Naime, većina praznika izmišljene tradicije, među kojima su i Nova godina po novom kalendaru i rođendanska slavlja, u Đurčićima se ne proslavlja. Posebno bih se osvrnula na proslavljanje rođendana, proizvod protestantskog modernističkog miljea, koji stanovnici Đurčića ne proslavljaju, čime potvrđuju svoj vjerski pravoslavni identitet. Uz to, ako se zna da pravoslavni Rusi slave imendan, koji je zapravo jedan fenomen predmoderne $e^{151}$ jer se vezuje za određenog sveca, te je religioznog porijekla, onda se neproslavljanje rođendana Đurčana može shvatiti i izrazom njihovog nacionalnog identiteta.

Svetkovanje krsne slave Đurđeva i proslavljanje sv. Save u Đurčićima ne samo što su očuvali integrativnu porodičnu, rodbinsku i prijateljsku funkciju, omogućili članovima mikrozajednice

\footnotetext{
148 Savićević M., op. cit.

149 Dragićević Šešić M., op. cit., str. 757.

150 Ibid., str. 757.

151 Habermas J., A ,post-secular” society - what does that mean?, 07.11.2009, http://www.resetdoc.org/EN/Habermas-Istanbul.php
} 
i njihovim potomcima iskazivanje i potvrđivanje ličnog, kolektivnog, vjerskog i nacionalnog identiteta, nego upućuju na još jednu činjenicu u vezi s korišćenjem slobodnog vremena aktera ove ruralne zajednice. Televizija je stvorila novu simboličku matricu ${ }^{152}$, mijenjajući odnos između javnog i privatnog, između formalnog i popularnog, između lokalnog, nacionalnog i internacionalnog. I u ovoj mikrozajednici, televizija je vodeće sredstvo javne komunikacije, kao izvor saznanja (prvenstveno kroz praćenje informativnih emisija) i izvor razonode i zabave (komične serije, zabavne emisije). Međutim, zabave masovnih medija $^{153}$ dio su svakodnevlja $\mathrm{i}$ ispunjavaju slobodno vrijeme stanovnika Đurčića, ali ne zamjenjuju ekskluzivnost zabave $u$ igri, tj. igranje, pjevanje i sviranje, tokom efemernih svetkovina kao što su krsna slava Đurđevo i slavljenje sv. Save. Uticaj elektronskih medija, radija i televizije, očigledan je i pri proslavljanju ovih praznika u selu, jer se upravo tada sviraju i pjevaju novokomponovane narodne pesme $e^{154}$ ili nove narodne pesme ${ }^{155}$, koje su najrašireniji oblik masovne kulture u poslijeratnoj Jugoslaviji. ${ }^{156}$ Novokomponovane pjesme svojom implicitnom kritikom socijalističkog društva imaju djelimično subverzivni karakter, ${ }^{157}$ tako da se mogu smatrati vrstom otpora publike prema dominantnoj kulturi. Za ovu publiku ozbiljna muzika nije bila alternativa, a narodnu muziku nije bilo moguće iskorijeniti na radiju i na televiziji. ${ }^{158}$ Početkom šezdesetih godina elektronski mediji su od restriktivne politike prešli na popustljivost, puštajući u svoje programe više narodnjačkih sadržaja, koje su do tada neuspjelo pokušavali potisnuti, piše Janjetović. Širenju ove muzike pogodovao je i porast broja radio i TV aparata, a vlasti su od sredine sedme decenije počele popuštati konzumerističkim sklonostima stanovništva. Prebrza urbanizacija, rast standarda i dostupnost medija, neuspjeh širenja obrada izvornih narodnih pjesama stvorili su uslove da se jedan broj kafanskih pjevača vine u visine jugoslovenskog socijalističkog šou-biznisa, zaključuje Janjetović. Ove zvijezde i njihove pjesme poznaju i pjevaju i Đurčani.

152 Korner Dž., op. cit., str. 261.

153 Burdije P., Klasni ukusi i životni stilovi, u: Studije kulture: zbornik, priredila Đorđević J., Beograd 2008, str. 166.

154 Golemović O. D., Čovek kao muzičko biće, Beograd 2006, str. 245.

155 Čolović I., Nove narodne pesme, Kultura br. 57-58, Beograd 1982, str. 29-55.

156 Dragićević Šešić M., Neofolk kultura: publika i njene zvezde, Sremski Karlovci, Novi Sad 1994, str. 11-21.

157 Kronja I., Potkultura „novokomponovanih”, Kultura br. 99, Beograd 1999, str. 104

158 Janjetović Z., „Selo moje lepše od Pariza”: narodna muzika u socijalističkoj Jugoslaviji, Godišnjak za društvenu istoriju br. 3, Beograd 2010, str. 67. 


\section{BORISLAVA VUČKOVIĆ}

Ovakav razvoj događaja potvrđuje Burdijeovu tezu da je televizija savršeno udešena po mjeri mentalnih struktura široke publike, ${ }^{159}$ koja se rukovodi populističkim spontanizmom i demagoškim potčinjavanjem, dok ovaj autor smatra da je neophodno istinski demokratsko korišćenje sredstava difuzije. ${ }^{160}$ Svojom rasprostranjenošću i izvanrednom moći uticaja, televizija stvara efekte koji su, iako ne bez presedana, potpuno novi, smatra Burdije. ${ }^{161}$ Televizija postaje instrument simboličkog nasilja jer ne samo da prenosi sliku stvarnosti već je i iz osnova oblikuje. ${ }^{162}$ Ono što nam je dobačeno, piše Anders (Günther Anders) u svojim filozofskim razmatranjima, ${ }^{163}$ jeste fantom (forme koje nastupaju kao stvari, otisak matrice) koji treba postati naša matrica jer se trebamo preinačiti prema njegovoj slici kako nikakav drugi svijet ne bismo imali kraj nje. Međutim, prodor elektronskih medija u ovu ruralnu sredinu nije ugrozio lični, porodični, socijalni, vjerski, moderni nacionalni identitet članova mikrozajednice u periodu socijalističke Jugoslavije, ali i oni dolaze pod uticaj totalitarizacija ili globalizacija do kojih, po Viriliovom (Paul Virilio) mišljenju, dolazi na svakom lokalitetu. ${ }^{164}$

U elektronskom eteru savremenih sredstava za telekomunikaciju Virilio prepoznaje privlačnost kraja prostora u kojem lebdi jedna mala planeta. ${ }^{165}$ Ovaj autor primjećuje da prisustvujemo kraju geografije, umjesto prerano najavljenog kraja Istorije ${ }^{166}$ Fukujame (Francis Fukojama). O toj velikoj globalnoj mutaciji, onoj koja okreće lokalitet prema spoljnom svijetu - i to svaki lokalitet - Virilio piše da ona više ne proganja, kao juče, ljude i čitave populacije, već mjesto njihovog života $i$ ekonomskog opstanka. Globalna delokalizacija koja oduzima prirodi njen identitet, i to ne samo nacionalni nego i socijal$n i$, dovodeći u pitanje ne toliko nacionalnu državu koliko grad, geopolitiku nacija. ${ }^{167}$

159 Burdije P., op. cit., str. 66.

160 Ibid., str. 69.

161 Ibid., str. 64, 65-66.

162 Ibid., str. 32.

163 Anders G., Svet kao fantom i matrica: filozofska razmatranja o radiju $i$ televiziji, Novi Sad 1996, str. 19-158.

164 Virilio P., Informatička bomba, Novi Sad 2000, str. 12.

165 Ibid., str. 12.

166 Fukujama F., Kraj istorije i poslednji čovek, Podgorica 1997.

167 Virilio P., op. cit., str. 15. 


\section{LITERATURA:}

Anders G., Svet kao fantom i matrica: filozofska razmatranja o radiju i televiziji, Novi Sad 1996.

Baćani T., Kulturna djelatnost, u: Podravsko-slatinski kraj: zbornik u povodu proslave četrdesetogodišnjice narodnog ustanka i socijalističke revolucije - vođenog pod rukovodstvom Komunističke partije Jugoslavije i druga Tita, urednik Baćani T., Podravska Slatina 1982.

Barvajz P. i Gordon D., Ekonomija i mediji, u: Uvod u studije medija, priredili Brigs A. i Kobli P., Beograd 2005.

Brejtvejt B., Police pretrpane časopisima, u: Uvod u studije medija, priredili Brigs A. i Kobli P., Beograd 2005.

Brigs A. i Kobli P., Šta su mediji: uvod, u: Uvod u studije medija, priredili Brigs A. i Kobli P., Beograd 2005.

Burdije P., Habitus i prostor stilova života, Kultura br. 109-112, I knjiga, Beograd 2005.

Burdije P., Klasna funkcija umetnosti, Kultura br. 32, Beograd 1976.

Burdije P., Klasni ukusi i životni stilovi, u: Studije kulture: zbornik, priredila Đorđević J., Beograd 2008.

Burdije P., Narcisovo ogledalo: rasprava o televizijskom novinarstvu, Beograd 2000.

Clarke J., Hall S., Jefferson T. i Roberts B., Subcultures, cultures and class, in: Resistance Through Rituals - Youth Subcultures in Post-war Britain, eds. Hall S. i Jefferson T., London, New York 2006.

Čolović I., Nove narodne pesme, Kultura br. 57-58, Beograd 1982.

Dragićević Šešić M., Neofolk kultura: publika i njene zvezde, Sremski Karlovci, Novi Sad 1994.

Dragićević Šešić M., Oblici čitalačke recepcije, Kulturni život br. 7-8, Beograd 1987.

Dragićević Šešić M., Privatni život u vremenu televizije, u: Privatni život kod Srba u dvadesetom veku, priredio Ristović M., Beograd 2007.

Dragićević Šešić M., Seoska porodica na razmeđu tradicionalne i masovne kulture, u: Zbornik Matice srpske za društvene nauke br. 86-87, Novi Sad 1989.

Đukić A., Televizija, Beograd 2007.

Fukujama F., Kraj istorije i poslednji čovek, Podgorica 1997.

Gavrilović Lj., Odevanje između javnog i privatnog, u: Privatni život kod Srba u devetnaestom veku: od kraja osamnaestog veka do početka Prvog svetskog rata, uredili Stolić A. i Makuljević N., Beograd 2006.

Golemović O. D., Čovek kao muzičko biće, Beograd 2006. 


\section{BORISLAVA VUČKOVIĆ}

Habermas J., A ,post-secular” society - what does that mean?, 07.11.2009, http://www.resetdoc.org/EN/Habermas-Istanbul.php

Hobsbom E., Uvod: kako se tradicije izmišljaju, u: Izmišljanje tradicije, priredili Hobsbom E. i Rejndžer T., Beograd 2002.

http://www.ebu.ch/en/about/index.php, 22.07.2011.

Ilić J., Broj i razmeštaj Srba na teritoriji avnojske Hrvatske, u: Srbi u Hrvatskoj: naseljavanje, broj i teritorijalni razmeštaj, uredio Rudić V., Beograd 1993.

Imširović J., Od staljinizma do samoupravnog nacionalizma: prilog kritici socijalizma u kongresnim dokumentima KPJ/SKJ V-VIII kongresa, Beograd 1991.

Janjetović Z., „Selo moje lepše od Pariza”: narodna muzika u socijalističkoj Jugoslaviji, Godišnjak za društvenu istoriju br. 3, Beograd 2010.

Janjetović Z., Od „Internacionale” do komercijale: popularna kultura u Jugoslaviji 1945-1991, Beograd 2011.

Jekel E., Kinematografija u Evropi, u: Uvod u studije medija, priredili Brigs A. i Kobli P., Beograd 2005.

Kelner D., Medijska kultura: studije kulture, identitet i politika između modernizma i postmodernizma, Beograd 2004.

Konačni rezultati popisa stanovništva od 15 marta 1948 godine, knjiga V, Beograd 1955.

Korner Dž., Televizija i kultura: obaveze i zadovoljstva, u: Britanske studije kulture: geografija, nacionalnost i identitet, priredili Morli D. i Robins K., Beograd 2003.

Kosanović D., Film i kinematografija (1896-1993), 08.08.2011, http:// www.rastko.rs/isk/isk_27.html,

Krizel E., Radio: javni servis, komercijalizacija i paradoksi izbora, u: Uvod u studije medija, priredili Brigs A. i Kobli P., Beograd 2005.

Kronja I., Potkultura „novokomponovanih”, Kultura br. 99, Beograd 1999.

Makluan M., Poznavanje opštila - čovekovih produžetaka, Beograd 1971.

Matić M., Počeci popularne kulture, Kultura br. 125, Beograd 2009.

Mik A., Benjamin, televizuelno i „fašistički subjekt”, Kultura br. 125, Beograd 2009.

Mikašinović Grujić R., Homogenizacija društva kao posledica dejstva televizije, Kultura br. 35, Beograd 1976.

Negrin R., Medijske institucije u Evropi, u: Uvod u studije medija, priredili Brigs A. i Kobli P., Beograd 2005.

Palmer Dž., Informativne vrednosti, u: Uvod u studije medija, priredili Brigs A. i Kobli P., Beograd 2005. 


\section{BORISLAVA VUČKOVIĆ}

Paterson R., Skica za analizu savremene televizije, u: Uvod u studije medija, priredili Brigs A. i Kobli P., Beograd 2005.

Petranović B., Jugoslovensko iskustvo srpske nacionalne integracije, Beograd 1993.

Radić R., Srpsko društvo u 20. veku između dve vere: privatno i javno, u: Privatni život kod Srba u dvadesetom veku, priredio Ristović M., Beograd 2007.

Savićević M., Televizija, 08.08.2011, http://www.rastko.rs/isk/isk_29. html

Sonders D., Izdavaštvo knjiga kao industrija, u: Uvod u studije medija, priredili Brigs A. i Kobli P., Beograd 2005.

Šuker R., Marketing i medijacija popularne muzike, u: Uvod u studije medija, priredili Brigs A. i Kobli P., Beograd 2005.

Šušnjić Đ., Ribari ljudskih duša: ideja manipulacije i manipulacija idejama, Beograd 2004.

Timotijević M., Rađanje moderne privatnosti: privatni život Srba u Habzburškoj monarhiji od kraja 17. do početka 19. veka, Beograd 2006.

Todić M., Fotografija i propaganda, 05.03.2011, http://www.photopropaganda.com/predgovor.php

Todić M., Na ludom kamenu: fotografija i ceremonija građanskog venčanja u Srbiji 1850-1940, u: Na ludom kamenu: venčana fotografija u Srbiji 1850-1998, urednica Bjeladinović Jergić J., Beograd 2002.

Todić M., Vek reklame, u: Kupite nešto i ovde, urednik Petrović G., Beograd 2010

Veljanovski R., Javni RTV servis u službi građana, Beograd 2005.

Virilio P., Informatička bomba, Novi Sad 2000. 
BORISLAVA VUČKOVIĆ

\author{
Borislava Vučković \\ University of Arts in Belgrade, Interdisciplinary PHD Studies
}

THE MEDIA CULTURE OF ĐURČIĆI PEOPLE

\begin{abstract}
The study of the media culture of the Đurčići rural micro-community members on the Papuk Mountain in Slavonia from 1945 to 1991 indicates integration of this population which followed global developments in the Yugoslav socialist state and also integration in McLuhan's global village, in accordance with their financial capacities. Reception of the press, film, radio and television takes place at a collective level, a form typical of "folk" in general, which opens the possibility for creating a media culture habitat in the family and in the village. Acceptance of new media, according to the old patterns and certain generational variations, confirms Eric Hobsbawm's thesis that rural traditional patriarchal communities are not encapsuled and fossilized, and that their survival is possible thanks to the occurring changes. The new media in this micro-community have the integrative function.
\end{abstract}

Key words: media culture, Đurčići, socialist Yugoslavia, identity

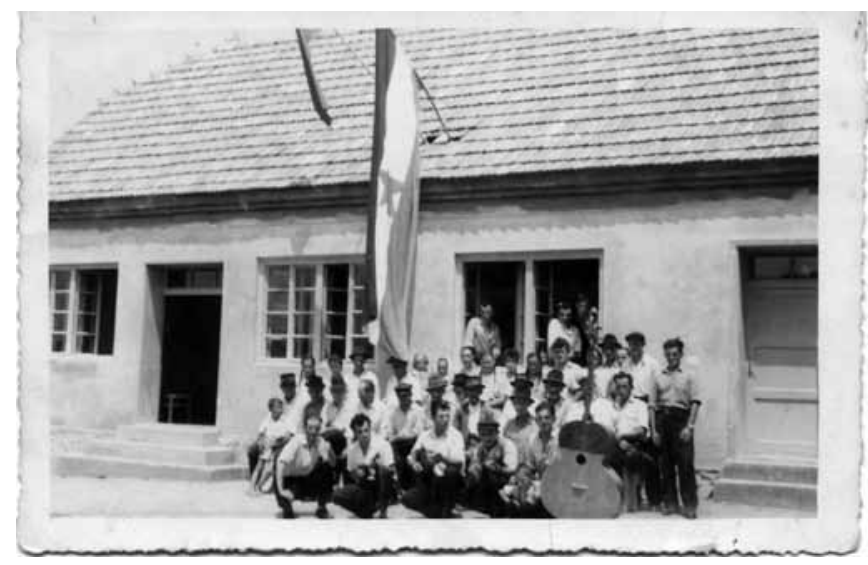

Seoski dom u Đurčićima u kome su prikazivani filmovi, 1950. godina Fotografska kolekcija Bogdanke (rođ. Vučković) Janić 